\title{
Development of Interactive Multimedia Blended Learning Based on Problem-Based Learning on Electrical Lighting Installation Subjects
} (Research and Development at Eleventh grade of Electrical Power Installation Engineering at Vocational High School 1 of Merdeka District)

\section{Guido Haga Sigiro}

Postgraduate of Educational Technology, State University of Medan, Medan - Indonesia Corresponding Email: gidoaga@gmail.com

\begin{abstract}
This research aims to analyze: (1) The Feasibility of Interactive Multimedia for Learning Electrical Installation Blended Learning based on Problem-based learning on the material of Installing Small Industrial Electrical Installation Components. (2) To improve Student Learning Outcomes using Interactive Multimedia for Learning Electrical Installations of Blended Learning Lighting based on Problem-based learning on the material for Installing Small Industrial Electrical Installation Components. Development is carried out using the Borg \& Gail development model, the development procedure adopted to produce instructional media products will be divided into 5 stages, namely (1) Phase I conducts Preliminary Research; (2) Phase II, Design; (3) Phase III, Product Development; (4) Phase IV, namely Product Review and Trial in the framework of Product revision; (5) The last stage, namely the effectiveness test which aims to determine the effectiveness of the product being developed. The effectiveness test was carried out in Eleventh grade 1 as the experimental class and Eleventh grade 2 as the control class. The learning process is carried out using interactive multimedia on the Remote Blended Learning Model in the experimental class.

The result of questioner that, has been given to the material expert, design expert, media expert get average 4,63 score, and for individual trail in small groups and for filed trail get average 4, 69 it is mean that Interactive Multimedia Blended Learning problem base learning media, is useful for Learning Electrical Installations.

Analysis technique data that used is descriptive technique. In normality test found from two class that $\mathrm{L}_{\text {count }}<\mathrm{L}_{\text {this table }}$

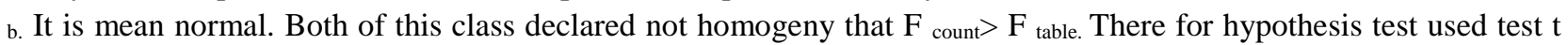
Independent. Equal $\mathrm{t}$ count $=4,154$ and $\mathrm{t}$ table $=2,021$ for $\mathrm{df}=48$, so that $\mathrm{t}$ count $>\mathrm{t}$ table for significant level $\alpha$ as big as 0,05 . Ho reject and Ha receive or in other word there are different results of student learning using Interactive Multimedia Blended Learning base on problem base learning compare to the result of student learning use power point media. The average of students learning of experiment class is $83,85 \%$ more than control class $76,67 \%$.
\end{abstract}

Keywords: Multimedia Interactive, Installation Learning Result, Blended Learning, Problem based learning.

\section{INTRODUCTION}

The world is now entering an era called the Industrial Revolution 4.0, starting from 2010s until now with the use of intelligent engineering and internet of thing as the main movement and human connectivity and machine to do production proses. According to Dunwill as stated by Delipiter (2019:33) said that there will be changes in future and calculate how learning classroom will be created over the seven years, namely: (1) Class change in physically or space (2) education perspective will be affected by virtual and augmented reality, (3) The assignment system will be more flexible, so it can qualify kinds of students' learning style and (4) The online learning will become an option for middle education. As stated by Aryani \& Norhayati (2018:315), that innovation 
interruption of Industrial Revolution 4.0 will generate Educations 4.0 that focused on education development and skills, so learning design that customized, hyper, intelligent, portable, global and virtual will be created.

Complexly, it can be said that students are able to qualify the demand of $21^{\text {st }}$ Century Learning. $21^{\text {st }}$ Century Learning is openness century that called Globalization era. This era give significant impact on various aspects of live, including aspect of education. Trilling \& Fadel (2009:15) said that competency of $21^{\text {st }}$ century education is needed in working world and life, namely (1) Life and working skills ; (2) Improving competency/learning and innovate skills; and (3) technology and media, information skills

According to Bencsik,Csikos, dan Juhez (2016:102), it showed that $\mathrm{Z}$ generation is generation who born in 1995- 2010. Berkup (2014:223) explained about characteristics of $\mathrm{Z}$ generation, namely in socializing in cyberspace, students can use internet so fast, by smartphone they can use internet efficiently and innovatively, and they also like game that challenge creativity.

Vocational High School 1 Merdeka Distric, is vocational school that focused on technology and engineering that is located in Kecamatan Merdeka, Kabupaten Karo North Sumatera - Indonesia. This school has some of skill competences; one of them is technique of Electrical Lighting Installation.

Anita Lie (2020:17) stated that in automation era and build Indonesia' human resources, teacher as facilitator of education process is expected to prepare students as smart people, that think critically and able to solve problem. That's why; the development of instructional design is really needed to support the ability of students to think critically.

Interactive multimedia that is combined with elearning will be more efficient. Students will be able to access learning anywhere and anytime. Measuring understanding can be done independently, after learning process that done authentically by quiz and students will used to comprehend concept by literacy of material that presented in interactive multimedia blended learning.

The researcher formulated this research as titled Development of Interactive Multimedia Blended Learning Based on Problem-Based Learning on Electrical Lighting Installation subjects in Eleventh grade of Electrical Power Installation Engineering at Vocational High School 1 Merdeka Distric. Based on the background of the study above, the problems of the study were formulated as follow (1) is interactive multimedia blended learning based on Problem- Based Learning on Electrical lighting installation subjects is proper to use in class XI, Vocational High School 1 Merdeka Distric? (2) is interactive multimedia blended learning based on Problem- Based Learning on Electrical lighting installation subjects can improve the study result of class IX, Vocational High School 1 Merdeka Distric?

\section{LITERATURE}

\subsection{Electrical Lighting Installation Learning}

According to Piaget, there are 2 schemata in organism that happened in all development level (invariant functional) namely assimilation and accommodation. Assimilation is how someone with cognitive structure can respond the environment. This process is about where someone found cognitive structure that derived from respond of manifestation to the environment. While, accommodation is how someone modify cognitive structure that derived from respond of manifestation to the environment. So, study is about the change of behavior that manifested from experience namely assimilation and accommodation process to the environment/ stimulus.

Winkel (1991) said that learning is complete action that designed to help students' learning activity that considering important experiences that have role of students experience process itself. Besides, Gagne in Evelin \& Hartini define learning as event arrangement that makes learning process can be useful. So it can be interpreted that learning is process of event arrangement that caused students experience intern process called learning.

Small industrial Electrical Installation Learning is setting process of action such arrange objective learning, prepare learning media that support students' learning style, decide activity that make students acquire information, assimilate and accommodate the experience about procedure of small industrial's electrical installation by deciding the appropriate component of electrical installation in an electrical lighting installation; analyze diagram of electrical lighting installation; design work diagram of electrical lighting installation.

\subsection{Interactive Multimedia Blended Learning}

Interactive multimedia based learning is the creation of communication between the user and the computers. The user communication occurred when operating computer with mouse, keyboard, or another input device as the medium (Elang, 2004:3), so interactive multimedia is a system in computer that combine text, picture, video animation, and audio that can be presented together and can produce interactivity or relations between computer media with the user that create stimulus and can be processed by many senses, so the user can accept and process the information that will be kept in their mind.

Garrison \& Vaughan (2008:3) explained that Blended Learning is the combination of face and online learning. The definition of Blended Learning according to Oliver dan Trigwell (2005:17) is (1) The combination of based web technology to achieve objective learning. (2) Combine some learning approaches that presented with or without technology design. (3) The combination of online and face learning (4) The combination of online 
teaching and assignment according Driscoll (2002), there are 4 concepts in Blended Learning, namely: (1) The combination of based web technology that designed to achieve objective learning. (2) The combination of learning approaches (such cognitivism, behaviorism, constructivism, connectivism) to achieve objective learning effectively with or without technology (3) The combination of technology based-product and face to face concept. (4) The combination of technology teaching and the actual work instruction to create positive impact of study and work. Based on the some definition of Blended Learning above, the definition of Blended Learning is emphasized by the first definition from Oliver and Trigwell' explanation and also Driscoll that stated Blended Learning is the combination of based web technology to achieve objective learning.

Meanwhile, Whitelock \& Jelfs (2003:5) stated 3 definitions of blended learning namely: (1) Traditional learning that integrated with web based-online learning (2) e-learning that combined with media and tools; and (3) The combination of some learning approaches. Based on the second definition from Whitelock and Jelf, it can be concluded that Blended Learning is the combination of media and tools into e-learning to achieve objective learning.

Blended Leaning is learning that combine some media and tools into e-learning, to achieve the objective of education. Based on the definition of interactive multimedia and blended learning above, Interactive multimedia and blended learning can be interpreted as a system that combine text, picture, video, animation and audio that can be presented together and can produce interactivity or relations between computer media with the user that create stimulus in learning that combined some media and tools into e-learning to achieve objective/goals education.

\subsection{Interactive Multimedia Blended Learning Based On Problem-Based}

In real life, we can't avoid problems. The students will be more engaged in learning if the learning context is related with real life. It is said by Moffit in Rusman (2012;241) about the definition of problem based learning that makes real life problem as the context that trigger us to think critically and improve problem solved skill, so the knowledge and important concept of material can be achieved. Interactive Multimedia Blended Learning Based on Problem-Based can be define as a system in computer that combine text, picture, video, animation, and audio that can be presented together and can produce interactivity or relations between computer media with the user that create stimulus in learning that combined some media and tools into e-learning to achieve objective/goals education with learning approaches that used real life problem as a context for students to think critically and problem solve skill and also to achieve knowledge and essential learning material. Based on Blended Learning syntax and Problem based learning syntax, syntax can be determined as follow:

Syntax design blended learning based on problem based learning is arranged as follow:

1. The first stage is seeking of information that consists of 3 stages in problem based learning syntax, namely problem orientation stages, organize student's stages, and investigate stages. This stage is appropriate with seeking of information syntax that emphasized good information that is related with information that support problem solving. In this stage, teacher also pays attention to students' activity to prepare student's organizing in group.

2. The second stage is acquisition of information that consist of a stage in problem based learning syntax, namely process, develop and present the result that produced from problem investigation and collecting information in each group discussion.

Table 1. Syntax Blended Learning based on Problem based Learning

\begin{tabular}{|l|l|l|}
\hline \multicolumn{2}{|c|}{ PHASE } & \multicolumn{1}{c|}{ TEACHERS BEHAVIOR } \\
\hline - & $\begin{array}{l}\text { Seeking Of Information } \\
\text { Problem oriented }\end{array}$ & $\begin{array}{l}\text { a. Delivery of objective learning, } \\
\text { b. Description of essential needed. } \\
\text { c. Students motivation to solve problem. } \\
\text { Assignment affirmation and organization in problem solving. }\end{array}$ \\
\hline $\begin{array}{l}\text { Individual and group } \\
\text { investigation. }\end{array}$ & $\begin{array}{l}\text { Accompaniment in collecting correct data, do experiment, collect } \\
\text { information as problem solving solutions. }\end{array}$ \\
\hline $\begin{array}{l}\text { Develop and present the } \\
\text { project. }\end{array}$ & $\begin{array}{l}\text { Accompaniment in planning and finishing a good project in video and the } \\
\text { other form, and also how to present and deliver it. }\end{array}$ \\
\hline $\begin{array}{l}\text { Analyze and evaluate } \\
\text { problem solving process. }\end{array}$ & $\begin{array}{l}\text { Accompaniment in reflecting the project and process that used in } \\
\text { investigation and planning. }\end{array}$ \\
\hline
\end{tabular}


3. The third stage is synthesizing of knowledge that consist of fifth stage in Problem based learning syntax namely presentation between each group in a class, students are asked to evaluate and analyze process of problem solving with the other groups.

\section{RESEARCH METHODOLOGY}

R\&D (Research and Development) model is chosen as development model in this research that called research and development model. This model is about research method that produces a product, and tests the product's effectiveness. This research uses research and development model that started with research and continued with the development. This research is done to get data about needs assessment, while the development is used to get media product namely interactive multimedia blended learning based on problem based learning that done in class XI Electrical Power Installation Engineering at Vocational High School 1 Merdeka District that use multimedia development model of combination learning Model Borg \& Gall and Dick \& Carey. namely (1) First stage, to do preface research (2) planning stage, (3) Third stage, product development (4) Forth stage namely review and product test (5) Last stage namely effective test.

\section{RESEARCH RESULT OF PRODUCT DEVELOPMENT}

Product that developed by using computer software for interactive multimedia is the main program, PowerPoint and Ispring suit 8 and the support program, Adobe Photoshop, Adobe Premier, Adobe Audition and Adobe Illustrator. Material that presented is a lesson about the procedure of Electrical Lighting Installation application and the example of Lighting Installation diagram in condition diagram form, implementation diagram and one line diagram. The learning material is developed into audio, video, visual, text and animation that combined in Content Management System (Website). The features in learning multimedia are as follow:

a. Login home.

This page is a first page in a website for login. Students enter the page to start the lesson.

b. Website Menu

This page provides basic competency that can be chosen as learning page. The user is expected to be able to choose basic competency that will be learnt. This development is using 3.7 basic competency of Electrical Lighting Installation component.

c. 3.7 Basic competency page

This page contains the objective learning that will be achieved and the learning stages that will be done in learning process.

d. First stage page $\&$ Interactive multimedia 1

This page is apperception stage, where students start the lesson by perceives basic knowledge about installation and small industry. By multimedia first stage, students are expected to find the example of small industry and installation requirement for small industry. To make sure that students have similar perception, they can do some quiz in interactive multimedia that has prepared. If the students pass it, they can continue to the next level. However, if they do not pass the quiz, they can play back the apperception video and rework the quiz. In this page, students are asked to answer questions in comment column as the question given in the last page. If there is question that need to be typed in comment column, students and teacher can answer or give opinion about it.

e. Second stage page.

This page us the second stage of problem oriented. Students observe the picture and problem that given. Then, students can give opinion or question about the picture and problem that shown by comment feature.

f. Third stage page and interactive multimedia 2 .

This page is the third stages that present multimedia with feature as follow:

1. Direction is a feature that used as a guide in using multimedia.

2. Procedure of component installation, is feature for learning the procedure of component installation that presented into video, picture and text for cable component, PHB, electric socked, switch, MCB, lamp and light fittings

3. Installation diagram is feature that used to learn about lane installation, the function of every component and network analysis that shown in condition diagram form, implementation diagram and one line diagram.

4. Quiz, is feature that used to test students understanding about material that presented in component installation feature and installation diagram. If the students finish with specified score, they can continue to the next level. However, if the students don't get specified score, they can learn and do the quiz again.

5. Glossary, is about term and the definition that used in multimedia. This page also provides comment column that can be filled with some questions or opinion. Teacher will also divide students group by comment column, so in the fourth stage students can choose group discussion page as each group.

g. Fourth stages, Group discussion

This page contains about guide discussion and feature group discussion option that consist of 4 groups. Students are expected to choose group that divided by their teacher. Students will be entering the discussion group; this part will be given discussion feature that can send text, audio, picture and video. If the discussion is over, the discussion results will be presented in fifth stages by zoom meeting.

h. Fifth stages, work presentation

This page is about structured meeting schedule namely Synchronous Online. Work presentation is done by zoom meeting that scheduled by teacher.

\section{PRODUCT FEASIBILITY TEST RESULT}

Based on the validation, interactive multimedia blended learning based on problem based learning in learning Electrical Lighting Installation is proper to use as 
learning media. Average score of Material expert is 4,66 so its stated that interactive multimedia Blended Learning based on Problem based learning in learning Electrical Lighting Installation is proper to because the material and submission criteria that require message for students. Average score of Learning Design expert is 4,50, so its stated that interactive multimedia Blended Learning based on Problem based learning in learning Electrical Lighting Installation is proper to use because it has met the learning standard. Average score of Media expert is 4,62, so its stated that that interactive multimedia Blended Learning based on Problem based learning in Electrical Lighting Installation subject is proper to use because it has met the principles and criteria of learning media development. Then, average score of individual trail is 4,61 , so its stated that interactive multimedia Blended Learning based on Problem based learning in Electrical Lighting Installation subject is proper to use. Average score of small group trail is 4,70, so its stated that interactive multimedia Blended Learning based on Problem based learning in Electrical Lighting Installation subject is proper to use. The last, average score of filed trail is 4,78 and it's also stated that interactive multimedia Blended Learning based on Problem based learning in Electrical Lighting Installation subject is proper to use in learning process. Based on the validation and the trail, interactive multimedia Blended Learning based on Problem based learning Electrical Lighting Installation is proper to use in learning process of Electrical Lighting Installation. So, this media is very proper to use in learning process of Electrical Lighting Installation to support the effectiveness of learning process. It's also stated by Arham and dwiningsih (2016: 113), that interactive multimedia can be used as learning innovation. This development media got good response from students as the consumer. Hadi and friends (2020:350) also stated that a learning presented with multimedia that controlled by computer will give attractive condition for students.

\section{PRODUCT EFFECTIVENESS TEST}

Product effectiveness test learning is interactive multimedia blended learning based on problem based learning in Electrical Lighting Installation learning by comparing the students' average study test score that learnt with learning product that has developed and students average test score by using power point. Both groups of study result data are analyzed with nonparametric statistic. It's because both groups of study result data do not qualify parametric statistic test, both groups have no homogeneity. It can be seen from average study result of students' Electrical Lighting Installation learning that used interactive multimedia. Blended Learning based on Problem Based Learning is $83,85 \%$. Meanwhile, average study result of students' Electrical Lighting Installation learning that used PowerPoint is $76,67 \%$. It proves that the use of Interactive Multimedia Blended Learning based on Problem Based Learning is more proper to use and effective to improve students' knowledge in learning Electrical Lighting Installation then the use of power point media.

\section{CONCLUSION}

The researcher conclude the development research of interactive multimedia blended learning based on Problem based learning in Electrical Lighting Installation learning as follow:

1. Development result of Interactive Multimedia Blended Learning based on Problem based learning in Electrical Lighting Installation Subject in class XI Electrical Lighting Installation, Vocational Hing School 1 Distric Merdeka that is product of this research is proper to use as final product to be applied and shared to product user. This statement is based on the validation feasibility result of material expert, learning design expert, media expert, even by individual, small group and field trial. With average 4 , 64 in assessment and test, so it's stated that it's proper to use.

2. Because the Mean of students study result that use interactive multimedia Blended Learning based on Problem based learning in Electrical Lighting Installation subjects is higher than students average study result that used PowerPoint media $(83,85 \%$ > $76,67 \%)$. So, it confirmed that interactive multimedia Blended Learning based on Problem based learning in Electrical Lighting Installation skill competency is effective to improve students study result.

\section{IMPLICATION}

According to the research conclusion and development result is obtained a high implication in the use of interactive multimedia blended learning based on problem based learning in Electrical Lighting Installation subject then learning media that used by teacher and students previously in learning activity. The implications are as follow:

1. Interactive multimedia blended learning based on problem based learning in Electrical Lighting Installation subject that has been researched and developed in competency skills installation procedure of electric lighting installation components helps students in learning the material by visual, audio, text, and interactive animation, so it helps students easier to understand the learning material and support their learning interest.

2. Interactive multimedia blended learning based on problem based learning in Electrical Lighting Installation subject that has been developed will make teacher easier to support learning process, so it gives positive effect to students study result.

3. Interactive multimedia blended learning based on problem based learning in Electrical Lighting Installation subject that has been developed will complete learning resource reference, in where the development result become a learning media and completeness document curriculum for Electrical Lighting Installation vocational competency.

4. In planning learning activities, teacher is expected to be able to choose learning media that suitable with basic competency. By choosing suitable and correct media, the main activity in lesson plan will improve 
students learning interest. Even though some of learning media have the strength and weakness, but the result of this media use can become an important consideration

\section{REFERENCES}

[1] Adav, Aman. Et al. (April 2011). Problem Based Learning: Influence on Students' Learning in an Electrical Engineering Course. Journal of Engineering Education, Vol. 100, No. 2, pp. 253280. http://onlinelibrary.wiley.com/doi/10.1002/html.

[2] Aida Aryani Shahroom, \& Norhayati Hussin. (2018). Industrial Revolution 4.0 and education. International Journal Academic Research in Business \& Social Sciences. 8(9): 314-319. from : https://hrmars.com/hrmars_papers/Industrial_Revol ution_4_0_and_Education.pdf

[3] Anderson, L. W. et al.(2001). A Taxonomy for Learning, Teaching and Assessing : A revision of Bloom's Taxonomy of Educational Objective's. New York. Addison Wesley Longman. Inc.

[4] Arends, Richard. (2008). Learning to Teach. Jogjakarta: Pustaka Pelajar

[5] Ariyanti D., Mustaji., \& Harwanto. (2020). Multimedia Interaktif Berbasis Ispring Suite 8. Jurnal Education and development.8(2): halaman 381-389.

[6] Anita Lie, dkk (2020). Mengembangkan Keterampilan Berpikir Tingkat Tinggi. Yogyakarta: PT.Kanisius

[7] Ayala. (2009). The Theory and Practice of Item Response Theory. New York: The Guilford Press

[8] Bencsik, A., \& Machova,R. (2016, April). Knowlage Sharing Problems from the viewpoint of intergeneration Manegement. In ICMLG2016 - 4th International Conferenceon Management, Leadership and Govermance: ICMLG2016 (p.42) Academic Conferences and Publishing Limited.

[9] Bencsik, A., Csikos,G., \& Juhaz,T. (2016). Y and Z Generations at Workplace. Journal of Competitivesness, $8(3), \quad 90 \quad-\quad 106$. https://doi.org/10.7441/joc.2016.03.06

[10] Berkup,S.B (2014). Working With Generations X And Y In Generation Z Period: Management Of Different Generations In Business Life. Rome-Italy: Mediterranean Journal of Social Sciences. Vol 5 No 19, Page: 218-229. DOI: 10.5901/mjss.2014.v5n19p218

[11] Bonk, C. J. \& Graham, C. R. (2005). The Handbook of blended learning: global perspectives, local designs.

https://books.google.co.id/books?hl=en\&lr=\&id=2 u2TxK06PwUC\&oi=fnd \&pg=PT14\&dq=blended + learning+definition \&ots $=\mathrm{a} 0 \mathrm{yUF} 89 \mathrm{~F} 61 \&$ sig $=\mathrm{KCd}-$ d_ZbRHcQUsuMybOb0O02bac\&redir_esc $=y \# v=0$ nepage $\& q=$ blended $\% 20 \%$ 20learning $\% 20$ definition $\& \mathrm{f}=$ false

[12] Bruner, Jerome. S. (1966). Toward a Theory of Instruction. Cambridge: Harvard University.

[13] Dastbaz, Mohammad. (2003). Designing Interactive Multimedia System. NewYork : McGraw-Hill Company.

[14] Delipiter,L. (2019).Pendidikan di Era Revolusi 4.0. SUNDERMAN Jurnal Ilmiah Teologi Pendidikan Sains Humaniora dan Kebudayaan. DOI: 10.36588/sundermann.v1i1.18

[15] Dongsong, Z., Zhao, J. L., Lina, Z. \&Nunamaker, J. J. F. (2004). Can e-learning replace classroom learning? Communications of the ACM,47(5), 7579. DOI: $10.1145 / 986213.986216$

[16] Elang Krisnadi (2004). Pemanfaatan Program CAI sebagai Sarana untuk Membantu siswa dalam Menyerap konsep-konsep Matematika dengan pendekatan Abstrak-konkret. Jakarta: pustekkom dan Pusat Informasi.

[17] Elang Krisnadi, Jurnal Pendidikan : Membangun Konstruksi Pengetahuan Siswa dalam Pembelajaran Matematika melalui Pemanfaatan Program Multimedia Interaktif (PMI)

[18] Grant Ramsay (2001) Teaching and Learning With Information and Communication Technology: Succes Through a Whole School Approach. National Educational Computing Conference, July 25-27. Chicago

[19] Hofstetter, Fred T. (2001). "Multimedia Literacy. Third edition. McGraw-Hill International Edition": New York.

[20] Holden, Jolly T. dan Philip J.L. Westfall. (2006). An Instructional Media Selection Guide for Distance Learning. Amerika: USDLA.

[21] Kimble, G. A. (1961). Hilgard and marquis' conditioning and learning. New york: appletoncentury-crofts

[22] KusumaN. R., Mustami M. K., \& Jumadi O. (2018). Pengembangan Media Pembelajaran Interaktif Power Point IspringSuite 8pada Konsep Sistem Ekskresi Di Sekolah Menengah Atas. Eprints Jurnal Universitas Negeri Makasar.28: halaman 1-8.

[23] Mahmed Sahin (2010). Blended Learning in Vocation Education: An Experimental Study. 
International Journal of Vocational an Technical Education Vol.2(6),pp.95-101,October 2010 from: DOI: $10.18415 /$ ijmmu.v3i2.46

[24] Nusir, S. (2013). Studying the Impact of Using Multimedia Interactive Programson Children's Ability to Learn Basic Math Skills. Sage Journals. 10(3), 305-319. Retrieved from https://journals.sagepub.com/doi/abs/10.2304/elea. 2013.10.3.305

[25] Rusman, (2012). Model-model Pembelajaran: Mengembangkan Profesionalisme Guru, RajaGrafindo Persada, Jakarta

[26] Rusman. (2013). Metode-Metode Pembelajaran: Mengembangkan Profesionalisme Guru. Jakarta: PT RajaGrafindo Persada.

[27] Siti Nur Kholifah (2016). Pengaruh model pembelajaran blended learning terhadap hasil belajar dan motivasi belajar siswa kelas xi tei pada mata pelajaran komunikasi data dan interfacedi smk negeri 1 jetis mojokerto. Jurnal Pendidikan Teknik Elektro. Volume 05 Nomor 03Tahun 2016, 975-982 from:

https://jurnalmahasiswa.unesa.ac.id/index.php/jurn al-pendidikan-tekniklektro/article/view/16816/15280

[28] Sjukur,S.B. (2012). Pengaruh Blended Learning terhadap Motivasi Belajar dan Hasil Belajar Siswa Tingkat SMK. Jurnal Pendidikan Vokasi. 2(3). h. 368-378.

DOI:https://doi.org/10.21831/jpv.v2i3.1043

[29] Smaldino, Sharon E, dkk (2012). Instructional Technology \& Media For Learning.Pearson: Education. Inc.

[30] Sriadhi. (2018). Instrumen Penilaian Multimedia Pembelajaran, Universitas Negeri Medan. https://www.researchgate.net/publication/3345868 89

[31] Tolman, E. C. (1932). Purposive Behavior in Animals and Men. New York : Century

[32] Trilling and Fadel (2009). 21st century skills: learning for life in our times. Jossey Bass: USA

[33] Vaughan, Tay. (2011). "Multimedia: Making It Work. 8th Edition”. New York : McGraw-Hill 